\title{
Predicting biomass of five shrub species in northeastern California
}

\author{
ROBIN S. VORA
}

\begin{abstract}
Volume, crown diameter, and number of twig were all highly correlated with biomass of individual shrubs of bitterbrush (Pwrshia tridentata (Pursh)DC), greenleaf manzanita (Arctostaphylos patula Greene), bis sngebrush (Artemisia tridentata Nutt.), snowbrush (Ceanothus velutinus Doug. ex. Hook), and gray rabbitbrush (Chrysothamnus nauseosus (Pall.)Britton). These variables were used to develop equations to predict above-ground dry welght; $R^{2}$ values varied from 0.76 to 0.98 . Oven-dry weights were 39 to $71 \%$ of live weight in the field.
\end{abstract}

Key Words: Purshia tridentata, A retostaphylos patula, A rtemivia tridentata, Ceanothus velutinus, Chrysothamnus nauseosus

Biomass or volume estimates of shrub species are correlated closely with twig production (Peek 1970, Kie 1985) and may be used to estimate shrub biomass productivity. Biomass estimates may also be used as a habitat index value for shrub dependent wildlife species, as an estimate of fuel biomass available for energy production, as indices of level of brush competition with growth of conifer seedlings or site productivity, and to show changes resulting from natural plant succession or cultural treatment (Bentley et al. 1970, Murray and Jacobson 1982).

Rapid, nondestructive methods are needed to make biomass estimates because of the labor and expense necessary to clip and weigh large plants, and the need to preserve the ecosystem (Ludwig et al 1975). Methods to establish a relationship between easily obtained plant measurements and plant biomass include a technique termed dimension analysis (Whittaker 1970); shrub biomass is estimated using regression analysis (Whittaker 1966, Newbould 1967, Rutherford 1979).

Biomass estimates of various shrub species and plant fractions have been developed using stem diameter, crown diameter, crown volume, crown cover, and height $X$ circumference as independent variables (Murray and Jacobson 1982). Bartolome and Kosco (1982) used basal diameter of branches arising from the primary stem (2nd order stems) to predict leaf and branch weights of deerbrush (Ceanothus integerrimus H.\&A.) using an allometric transformation in linear regression. Crown diameters and heights were used to estimate biomass of 3 tip sagebrush (Artemisia tripartita Rydb.) and Douglas rabbitbrush (Chrysothamnus viscidiflorus (Hook.)Nutt.) in Idaho (Murray and Jacobson 1982). Rittenhouse and Sneva (1977) used log transformations of width and height to predict biomass of Wyoming big sagebrush (Artemisia tridentata Nutt. ssp. wyomingensis Beetle \& Young). Crown volume was used to predict dry weights of greenleaf manzanita (Arctostaphylos patula Greene) and snowbrush or tobacco brush (Ceanothus velutinus Doug. ex. Hook.) on the west slopes of the southern Cascade-Siskiyous (Bentley et al. 1970).

I developed predictive equations for above-ground dry weight for 5 major species: bitterbrush (Purshia tridentata (Pursh)DC), greenleaf manzanita, big sagebrush (Artemisia tridentata Nutt.), snowbrush, and gray rabbitbrush (Chrysothamnus nauseosus (Pall.)Britton) to study the effects of several timber harvest

\footnotetext{
The author did this work while at the University of Idaho, Moscow 83843. He is currently a wildlife biologist, U.S. Fish and Wildlife Service, 801 Gloucester St., Rm. 334, Brunswick, Ga. 31520. He thanks J. Peek for his assistance with developing methodology for this study; K. Toor, P. Schoreder, M. Lyons, and N. Finley for field assistance; $\mathbf{P}$. Mike for assistance with statistical analyses; and the following individuals for their editorial comments: R. Powers, D. Roy (deceased), C. Halvorson, D. Airola, and D. Owens.

Manuscript accepted 3 September 1987.
}

methods on understory vegetation on Blacks Mountain Experimental Forest in northeastern California. Relationships between wet and dry weights were also calculated.

\section{Study Site}

The Blacks Mountain Experimental Forest is located on the Lassen National Forest, Lassen County, California. Approximately half of the forest lies in a gently rolling basin; the rest extends up moderate slopes to the north and east. Elevations vary from 1,700 to $2,100 \mathrm{~m}$.

The mixed-age forest stands are composed of small, even-aged groups of trees. The overstory is broken by groups of smaller size trees, or scattered older residuals in younger stands. Age classes are not evenly distributed spatially, but instead form a mosaic of small homogeneous units that vary in size from a fraction of a hectare to 4 ha (Hallin 1959).

Mean annual precipitation varies from 23 to $74 \mathrm{~cm}$, and averaged $46 \mathrm{~cm}$ during 1935-53 (Hallin 1959). About $90 \%$ of the precipitation is received in the months of October through May. McDonald (1983) states that soil moisture becomes depleted rapidly in this region. Warm summer temperatures and low humidity increase evapotranspiration to the point of creating moisturedeficient soils. Consequently, the growing season for an average ponderosa pine (Pinus ponderosa Laws), for example, lasts only from 1 May to about 15 June in a typical year.

\section{Methods}

Ten to 21 specimens of each of the 5 species were clipped to estimate total above-ground biomass (Table 1). Somewhat larger

Table 1. Range in dry weights (8) of amples.

\begin{tabular}{lccr}
\hline \hline Species & $\mathrm{n}$ & Smallest & Largest \\
\hline B. sagebrush & 20 & 9.8 & 1,524 \\
Bitterbrush & 20 & 4.8 & 1,805 \\
G. manzanita & 14 & 19.1 & 11,784 \\
G. rabbitbrush & 21 & 0.6 & 380 \\
Snowbrush & 10 & 347.1 & 15,040 \\
\hline
\end{tabular}

sample sizes (perhaps 20-25) for greenleaf manzanita and snowbrush would have been preferable; however, the size of individuals of these $\mathbf{2}$ plant species prevented clipping of additional specimens due to time restrictions and logistics associated with transporting the material from the field and through the mail to the drying oven. Plants were chosen to represent the full range of heights and forms encountered, and the range of elevational sites at which the species were found in the study area. Clippings were made during August 1983 and 1984. Specimens were weighed with a hand scale in the field to estimate wet weight. Field measurements (nearest $\mathrm{cm}$ ) taken on the shrub specimens included: maximum height; 2 diameters taken at right angles to each other across the canopy of the plant, 1 of which was the maximum diameter of the plant; total number of twigs; and indices of plant decadence (1-low, 2-medium, 3-high). A plant with a "high" decadence level had relatively few leaves and a large portion of its crown consisted of dead branches. Similarly, specimens of bitterbrush were assigned to 1 of 3 browse classes following the idea presented by Cole (1959). 
Clipped plant specimens were air dried, and then placed in a drying oven at $45^{\circ} \mathrm{C}$ for approximately 48 hours to remove atmospheric moisture prior to weighing. However, 2 specimens of big sagebrush were dried at $30^{\circ} \mathrm{C}$ in error.

The dependent variable (dry weight) was tested for normality of distribution using the Shapiro-Wilk statistic, $W($ SAS 1982). Natural $\log (\mathrm{ln})$ or square root transformations were made if necessary to obtain normal distribution of the residuals from regression analyses. The most common shrub form was an ellipsoid; therefore volume was calculated using height and the area of an ellipse$\mathrm{pi} / 4 \mathrm{~d}_{1} d_{2}$, where $d=$ diameter (Peek 1970). Independent variables were plotted against the dependent variable to examine for linear relationships (Table 2). Simple correlation coefficients were calculated and stepwise regression (backward, stepwise, and maximum

Table 2. Correlation coefiicients of dependent variables with dry weight of shrubs".

\begin{tabular}{|c|c|c|c|c|c|}
\hline \multirow[b]{2}{*}{ Dependent variables } & \multicolumn{5}{|c|}{ Species } \\
\hline & $(n=10)$ & $(n=20)$ & $(n=21)$ & $(n=14)$ & $(n=20)$ \\
\hline Height & 0.77 & $0.77^{b}$ & $0.78^{c}$ & $0.90^{\mathrm{b}}$ & $0.71^{\mathrm{c}}$ \\
\hline Average diameter & 0.91 & $0.98^{b}$ & $0.91^{\circ}$ & $0.93^{\mathrm{b}}$ & 0.85 \\
\hline Volume & 0.94 & $0.91^{\mathrm{b}}$ & $0.91^{\mathrm{c}}$ & $0.94^{\mathrm{b}}$ & 0.83 \\
\hline No. of twigs & 0.90 & $0.94^{c}$ & $0.89^{c}$ & $0.98^{b}$ & 0.69 \\
\hline Volume $\times \#$ twigs & 0.90 & $0.79^{\mathrm{b}}$ & $0.92^{\mathrm{c}}$ & $0.92^{c}$ & 0.85 \\
\hline (Avg. diameter) $)^{2}$ & 0.93 & $0.98^{\mathrm{b}}$ & $0.91^{\mathrm{e}}$ & $0.96^{\mathrm{b}}$ & 0.82 \\
\hline $\begin{array}{l}\text { Volume } \times \text { decadence } \\
\text { rating index }\end{array}$ & 0.99 & $0.89^{b}$ & $0.91^{\mathrm{c}}$ & $0.96^{b}$ & 0.87 \\
\hline $\begin{array}{l}\text { Twigs } \times \text { decadence } \\
\text { rating index }\end{array}$ & 0.87 & $0.80^{\mathrm{b}}$ & $0.83^{\mathrm{c}}$ & $0.92^{\mathrm{b}}$ & \\
\hline $\begin{array}{l}\text { Volume } X \text { browse index } \\
\text { No. twigs } X \text { browse index }\end{array}$ & & & & & $\begin{array}{l}0.80 \\
0.79\end{array}$ \\
\hline No. twigs $\times$ browse index & & & & & \\
\hline$X$ desadence rating & & & & & 0.79 \\
\hline
\end{tabular}

The prubability $>r<0.01$ for all correlation coefficients.

Square root transformation.

Natural log (In) transformation.

$R^{2}$ procedures) were used to derive predictive equations (SAS 1982). Alternate equations were developed with transformed variables (natural log or square root transformations) (Tables 2 and 3 ).

\section{Results}

Independent variables (except decadence rating) were all highly correlated with shrub biomass and with each other. These variables were used only in predictive equations if their effects were additive. Highest simple correlations were usually achieved with diameter, volume, and number of twigs (except bitterbrush) (Table 2).

The $R^{2}$ value of predictive equations, derived using stepwise regression procedures, varied from 0.76 for bitterbrush to 0.98 for greenleaf manzanita (Table 3). A natural $\log (\ln )$ transformation was used for gray rabbitbrush. Higher $\boldsymbol{R}^{2}$ values were obtained in predicting dry weight of greenleaf manzanita and big sagebrush by using square root transformations. Residuals for each of the regression equations (Table 3) were normally distributed $(\mathrm{PROB}<W \geq 0.02)$.

Dry weight of bitterbrush could not be predicted using both full plants and major parts of plants (e.g., 2nd order branches). Analysis of variance indicated a significant interaction $(P=0.029)$ between dry weight and plant "type" (part or full plant), thereby invalidating use of portions of the plant in conjunction with the full specimen.

One equation to predict dry weight from wet weight measured in the field could not be developed for use for all the shrub species because of the interaction among species (ANOVA, $P=0.015$ ), and the interaction of wet weight $X$ species interaction was significant (ANOVA, $P=0.036$ ). Thus, equations to predict dry weight from wet weight were derived for each species. Dry weight was $48 \%$ of wet weight for greenleaf manzanita, $71 \%$ for big sagebrush, $62 \%$ for snowbrush, $39 \%$ for gray rabbitbrush, and $60 \%$ for bitterbrush.

\section{Discussion}

These equations provide the manager and research scientist with tools to quickly estimate shrub biomass on Blacks Mountain Experimental Forest. The $\boldsymbol{R}^{2}$ values for greenleaf manzanita, big sagebrush, snowbrush, and gray rabbitbrush suggested that the regression equations (Table 3) were good predictors of dry weights for these species.

A comparison of the results to those derived by Bentley et al. (1970), for a site on the Shasta Trinity National Forest $80 \mathrm{~km}$ northwest of Blacks Mountain), suggests that these regressions may only apply to those sites upon which they were obtained. Peek (1970) and Peek et al. (1971) made similar observations with regression equations in Minnesota. Measurement techniques are also variable, and in some cases, subjective. The slope of Bentley et al.'s equation for greenleaf manzanita differs from mine by a factor of about 2. Figure 5, in their paper, shows the largest plants they measured were about 2,000 g. One specimen on Blacks Mountain Experimental Forest weighed $11,784 \mathrm{~g}$ (Table 1). Inclusion of larger plants would probably alter their regression coefficients. Bentley et al. (1970) visually adjusted for irregularities in crown width and height and thus calculated crown volumes that were more compact than those I derived using maximum height and widths. This may also be a reason why Bentley et al.'s (1970) regression coefficient for greenleaf manzanita was higher. Their ratios of dry weight/volume were similar to mine for snowbush. The equations I derived for use on Blacks Mountain Experimental Forest may only apply to areas having similar climate, soils, and vegetative associations in the eastside pine type of northeastern California.

Whittaker (1962) reported that the proportion of growth of a shrub which is distributed in current twigs and leaves decreases as the shrub matures. Plants growing under tree cover exhibited different form from those growing in open areas. This was especially true on Black Mountain in areas that were virgin forest or

Table 3. Equations used to predict weight (gms) of major shrub species on Bbeks Mountain Experimental Forest.

\begin{tabular}{|c|c|c|c|c|}
\hline Species & $\mathbf{n}$ & Predictive equation" & MSE $^{\mathbf{b}}$ & $R^{2}$ \\
\hline $\begin{array}{l}\text { Greenleaf } \\
\text { manzanita } \\
\text { Big } \\
\text { sagebrush } \\
\text { Snowbrush } \\
\text { Gray rabbitbrush } \\
\text { Bitterbrush }\end{array}$ & $\begin{array}{l}14 \\
20 \\
10 \\
21 \\
20\end{array}$ & $\begin{array}{l}\text { (dry weight) })^{1 / 2}=-2.90+0.24 \times \text { (average diameter) }+0.08(\# \text { twigs }) \\
\text { Alt: dry weight }=-1082.11+4.83 \times(\text { average diameter })+14.49 \times(\# \text { twigs }) \\
\text { (dry weight) } 1 / 2=-9.69+0.26 \times(\text { average diameter })+2.9 \times \ln (\# \text { twigs }) \\
\text { Alt: dry weight }=170.38+6.28 \times(\text { average diameter })+1.95 \times(\# \text { twigs }) \\
\text { dry weight }=-461.07+0.009 \times(\text { volume })+12.15 \times(\# \text { twigs }) \\
\text { In (dry weight) }=-4.67+0.56 \times \ln (\text { volume } \times \text { twigs }) \\
\text { dry weight }=77.65+0.06 \times(\text { average diameter })^{2}+0.0000014 \times \text { (volume) }\end{array}$ & $\begin{array}{c}22.95 \\
1738035 \\
4.24 \\
10921 \\
1136750 \\
0.41\end{array}$ & $\begin{array}{l}0.98 \\
0.87 \\
0.96 \\
0.94 \\
0.95 \\
0.85\end{array}$ \\
\hline & & Alt: dry weight $=-2.268+0.10 \times(\text { average diameter })^{2}$ & $\begin{array}{l}63284 \\
70826\end{array}$ & $\begin{array}{l}0.80 \\
0.76\end{array}$ \\
\hline
\end{tabular}

Alt: = Alternate equation; equations in which the dependent variable is transformed using natural logarithms may be used in the following manner: $\ln (\mathrm{dry}$ weight $)=\mathrm{a}+\mathrm{bx} \rightarrow>$ dry weight $=e^{(a+b x+1 / 2(M S E))}$.

MSE = Mean square error of analysis of variance. 
had not been cut in $\mathbf{4 0}$ years. Plants growing under tree cover were lanky and high in total volume and dead biomass. Conversely, they were low in total and live biomass and number of twigs. Therefore, number of twigs was included in the stepwise regression analyses to correct for plant form and decadence.

Plants were also assigned to 1 of 3 decadence classes. These decadence ratings by themselves could not be correlated with dry weight. For snowbrush, greenleaf manzanita, and bitterbrush, however, the decadence rating $(1,2$, or 3$)$ multipled by volume was somewhat more strongly correlated with dry weight than volume alone (Table 2). Adjustment for irregularities in the crown (Bentley et al. 1970) would be an alternative, but is somewhat subjective, like my decadence rating, and is more time consuming.

A single solid (ellipsoid) was used to calculate volume for all species. Correlations between dry weight and volume were high $(r>0.90)$, except perhaps with bitterbrush $(r=0.83)$ (Table 2). Other forms of solids (sphere, cone, upper-half spheroid, etc.) may have provided even better correlations for some species. Natural shapes of canopies were highly variable for all 5 species.

Bitterbrush was the only shrub species that received noticeable browsing (primarily by cattle). Severe browsing of this species resulted in plants that had the appearance of a dense, low hedge. The $R^{2}$ value for the bitterbrush equation is lower than the rest ( $R^{2}$ $=0.76$ ), suggesting that further investigation of predictor variables for bitterbrush, including adjustments for form and degree of browsing, may yield a better predictive equation. Inclusion of browse class as a predictive variable, however, did not improve correlations with dry weight (Table 2).

Peek (1970) suggested that a stable relationship between shrub canopy area and weight would occur when a stable overstory canopy has developed, or when a shrub community has matured to where further growth is minimal and decadence is not appreciable. My observations in the eastside pine type do not suggest that such a stable relationship ever occurs. The forest is heterogeneous. Understory shrubs increase in decadence and may die as tree cover increases. But gap openings, caused by fire, insect and disease kills of trees, and timber harvest, permit another round of shrub rejuvention and active growth. Such openings are numerous in "overmature", virgin forests of northeastern California and are evidence of dynamic changes.

\section{Literature Cited}

Bartolome, J.W., and B.H. Kosco. 1982. Estimating browse production by deerbrush (Ceanothus integerimus). J. Range Manage. 35:671-672.

Bentley, J.R., D.W. Seezrist, and D.A. Blakeman. 1970. A technique for sampling low shrub vegetation by crown volume classes. USDA Forest Serv. Res. Note. PSW-215.

Cole, G.F. 1959. Key browse survey method. Proc. West. Ass. State Fish \& Game Comm., Portland, Ore.

Hallin, W.E. 1959. The application of unit area control in the management of ponderosa-Jeffrey pine at Blacks Mountain Experimental Forest. USDA Forest Serv. Washington, D.C. Tech. Bull. 1191.

Kie, J.G. 1985. Production of deerbrush and mountain whitehorn related to shrub volume and overstory crown closure. USDA Forest Serv. Res. Note PSW-377.

Ludwig, J.A., J.F. Reynolds, and P.D. Whitson. 1975. Size-biomass relationships of several Chihuahuan desert shrubs. Amer. Midl. Natur. 94:451-461.

McDonald, P.M. 1983. Climate, history, and vegetation of the eastside pine type in California. P. 1-16. In: T.F. Robson and R.B. Standiford (eds). Management of the eastside pine type in northeastern California, proceedings of a symposium. N. Calif. Soc. Amer. Forest. 83-06. Arcata, Calif.

Murray, R.B., and M.Q. Jacobson. 1982. An evaluation of dimension analysis for predicting shrub biomass. J. Range Manage. 35:451-454.

Newbould, P.J. 1967. Methods for estimating the primary production of forests. IBP Handbook No. 2, Blackwell Scientific Publ., Oxford, England.

Peek, J.M. 1970. Relation of canopy area and volume to production of three woody species. Ecology 51:1098-1101.

Peek, J.M., L.W. Krafting, and J.C. Tappeiner, II. 1971. Variation in twig diameter-weight relationships in northern Minnesota. J. Wildl. Manage. 35:501-503.

Rittenhouse, L.R., and F.A. Sneva. 1977. A technique for estimating big sagebrush production. J. Range Manage. 30:68-70.

Rutherford, M.C. 1979. Plant-based techniques for determining available browse and browse utilization: a review. Bot. Review 45:203-228.

SAS. 1982. SAS user's guide: statistics, 1982. ed. SAS Institute Inc., Cary, N.C.

Whittaker, R.H. 1962. Net production relations of shrubs in the Great Smoky Mountains. Ecology 43:357-377.

Whittaker, R.H. 1966. Forest dimensions and production in the Great Smoky Mountains. Ecology 47:103-121.

Whittaker, R.H. 1970. Communities and ecosystems. MacMillan Co., London.

\section{Moving in the near future?}

Please send us your change of address as soon as you can so you won't miss any issues of the Journal or Rangelands.

Please send your old address lable plus the following information to Society for Range Management: 1839 York Street, Denver, CO 80206.

Name
New Address
City
State

\section{ATTACH \\ OLD ADDRESS \\ LABEL HERE}

